\title{
Mobile Money Users' Functionings and Freedoms: Amartya Sen's Capability Approach
}

\author{
Odoyo Collins Otieno ${ }^{*}$, Samuel Liyala \\ School of Informatics and Innovative Systems, Jaramogi Oginga Odinga University of Science and Technology, Kenya
}

Copyright $\bigcirc 2018$ by authors, all rights reserved. Authors agree that this article remains permanently open access under the terms of the Creative Commons Attribution License 4.0 International License

\begin{abstract}
Over the last decade Amartya Sen's Capability Approach has emerged as the leading alternative to standard economic frameworks for thinking about poverty, inequality and human development generally. Professor Sen has developed, refined and defended a framework that is directly concerned with human capability and freedom [1]. This framework as it looks at peoples' freedoms and the means that enable them attain such freedoms, was found suitable for this study. This study therefore looked at mobile money users' functionings and freedoms in both rural and urban settings. The framework was therefore established to be suitable in studying societal development that focuses on the people, the development being yearned for and the means to attain such development.
\end{abstract}

Keywords Capability, Functioning, Freedom, Mobile Phone, Mobile Money, Services

\section{Introduction}

Mobile commerce, commonly known as m-commerce and electronic commerce, also known as e-commerce, are technologies that are becoming popular in Africa currently; although mobile commerce is perceived to in future surpass the electronic commerce as a method of digital transaction [2].

Mobile money services were introduced by private telecommunication providers in several countries around the world especially in Africa, Asia, and Latin America [3]. The concrete design of mobile money services may not be similar; however the focus was to enable cheap and reliable money transfers between people that have access to a mobile phone. This is relevant for sending and receiving remittances, which is much more expensive and sometimes risky through the traditional formal and informal mechanisms [4]. Also, mobile money facilitates transfers between business partners [5], thereby reducing transaction costs and promoting market integration and exchange. This service also provides secure opportunities for saving, even in remote rural areas [6].

\section{Materials and Methods}

\subsection{Research Approach}

The research approach adopted is qualitative because it was appropriate in understanding the dynamics of this study subject area. This approach was relevant to the study based on its interpretive nature as well as its abilities to generate and address multiple realities. The strength of qualitative research for this study was its ability to provide complex textual descriptions on mobile phone users' capabilities on mobile phone money use. As an approach, it provides information about; contradictory behaviors, beliefs, opinions, emotions, and relationships of individuals.

Qualitative methods are also effective in identifying intangible factors, such as social norms, socioeconomic status, gender roles, ethnicity, and religion, whose role in the research issue may not be readily apparent. The findings from qualitative data can often be extended to people with characteristics similar to those in the study population, which aids in gaining a rich and complex understanding of a specific social context or phenomenon and this typically takes precedence over eliciting data that can be generalized to other geographical areas or populations [7].

\subsection{Research Design}

Ethnography research design was adopted based on its usefulness and appropriateness for this particular study. Ethnography, emerging from anthropology, and adopted by sociologists, is a qualitative methodology that lends itself to the study of the beliefs, social interactions, and behaviors of small societies, involving participation and 
observation over a period of time, and the interpretation of the data collected [8]. It is very time consuming type of research, however, its main benefit is its depth, and therefore the contribution of rich insight to the subject being studied. One weakness is that it lacks breadth, as the focus is typically on one particular situation or phenomenon, leading to a criticism of lack of generalizability [9]. Also, the main data collection technique is participant observation [10].

Ethnography data consists of unstructured accounts and the analysis, which provides interpretation of meaning, and is done by the researcher, using observation, description and explanation [11].

\subsection{Location of the Study}

This study was conducted in Homa Bay Region, covering an area of $1,169.9 \mathrm{Km}^{2}$, and comprising of Homa Bay Town, Ndhiwa and Rangwe sub counties, in Homa Bay County in the Republic of Kenya. The area is located in South Western Kenya along Lake Victoria.

The study area enjoys the presence of five major banks namely: Barclays Bank, Kenya Commercial Bank, Cooperative Bank, Post Bank and Equity Bank. These banks are based in Homa Bay Town and Ndhiwa Sub Counties, where as Rangwe lacks the presence of any bank [12]. The rest of trading centers in the study area are served largely by Microfinance Institutions, SACCOs, and presently more than 60 banking agents [12]. Mobile money transfer services and agency banking is expected to grow very rapidly to expand access to banking in the area. The reason for conducting a study in this area was the fact the Homa Bay Region portrayed the desired characteristics that this study was looking for. The main characteristics it portrayed were rural and urban settings, middle-income earners and low-income earners, educated and non-educated individuals, all exist in this region.

\subsection{Target Population, Sampling Technique and Sample Size}

\subsubsection{Target Population}

Study population for this study was 167,358 people owning mobile phones in Homa Bay region of Homa Bay County as illustrated in table 1. This is a fraction of 325,453 people who have access to mobile phones [13], or total population, 366,620 people in Homa Bay region (Homa Bay Town, Ndhiwa and Rangwe sub-counties) according to 2009 Kenyan census results [14]. The same statistics indicated that a total of $\mathbf{8 5 6 , 9 4 6}$ people in Homa Bay County had access to mobile phone services, while 440,021 people owned mobile phones [14]; compared to the total population of Homa Bay County that was 963,794 people [13].

To ensure representative data, gender and age consideration was taken into account while selecting the informants. The population statistics for Homa Bay region as well as Homa Bay County is summarized in table 1.

Table 1. Homa Bay Region Access to Mobile Phone Services Population

\begin{tabular}{|c|c|c|c|}
\hline & Total Population & $\begin{array}{c}\text { Access to Mobile } \\
\text { Phone Services }\end{array}$ & $\begin{array}{c}\text { Owning Mobile } \\
\text { Phone }\end{array}$ \\
\hline $\begin{array}{c}\text { Homa Bay } \\
\text { Region }\end{array}$ & 366,620 & 325,453 & 167,358 \\
\hline
\end{tabular}

Source: KNBS, 2014a and KNBS, 2014b

\subsubsection{Sampling Technique}

This study used a triangulation of probability and non-probability sampling techniques, specifically, Stratified sampling and purposive sampling techniques [15] [16].

Since the participants to this study possess heterogeneous characteristics, stratified sampling was used when putting the target group into homogeneous subgroups for the effective process of data collection. The groups were categorized into three sub-counties, giving the initial three strata. In the three sub-counties, Homa Bay sub-county represented urban characteristics of mobile phone users, while both Ndhiwa and Rangwe sub-counties represented rural characteristics of users. This led to the next level of stratification, which categorized the study population into gender (male or female) and age (youth or the old).

Purposive sampling on the other hand was used to select the informant with desirable characteristics for this study, notably, those from the study area who enable the researcher to obtain divergent views about mobile phone users' capabilities to mobile phone money use. The sampling techniques were used to select the informants for both the interview and focus group discussions, from each of the last set of strata (male, female, youth and the old).

\subsubsection{Study Sample Size}

According to Flick [17], Morse [18] and Strauss \& Corbin [19], Sample sizes in qualitative research should not be too large that it is difficult to extract thick and rich data. The sample should also not be too small that will make it difficult to achieve data saturation, theoretical saturation.

Kothari [20] argues that, an optimum sample is one that fulfills the requirements of efficiency, representativeness, reliability and flexibility. The study adopted a triangulation of stratified and purposive sampling technique, to select mobile phone owners in the study area with the desired characteristics that was most likely going to yield the desirable results for this study. A total of 48 participants were selected for both the focus group discussion and interview. Out of the 48 participants, 16 participants were used for semi-structured interviews that were conducted to help in further identifying the main themes that were used in the focus group discussions. The other 32 participants were targeted for focus group discussions. The researcher 
conducted conduct 4 focus group discussions, one each for Ndhiwa and Rangwe sub-counties and two for Homa Bay Town sub-county. Each focus group discussion consisted of 8 participants (male youth, old male, female youth and old female). Table 2 illustrates clearly the sample.

Table 2. Sample size

\begin{tabular}{|c|c|c|c|c|c|c|}
\hline \multicolumn{7}{|c|}{ FOCUS GROUP DISCUSSION SAMPLE SIZE } \\
\hline & & \multicolumn{2}{|c|}{ MALE } & \multicolumn{2}{|c|}{ FEMALE } & \multirow{2}{*}{ TOTAL } \\
\hline & & YOUTH & OLD & YOUTH & OLD & \\
\hline URBAN & Homabay Town & 4 & 4 & 4 & 4 & 16 \\
\hline \multirow{2}{*}{ RURAL } & Ndhiwa & 2 & 2 & 2 & 2 & 8 \\
\hline & Rangwe & 2 & 2 & 2 & 2 & 8 \\
\hline \multicolumn{2}{|c|}{ TOTAL } & 8 & 8 & 8 & 8 & 32 \\
\hline \multicolumn{7}{|c|}{ INTERVIEW SAMPLE SIZE } \\
\hline & & \multicolumn{2}{|c|}{ MALE } & \multicolumn{2}{|c|}{ FEMALE } & \multirow{2}{*}{ TOTAL } \\
\hline & & YOUTH & OLD & YOUTH & OLD & \\
\hline & Homaba Town & 2 & 2 & 2 & 2 & 8 \\
\hline & Ndhiwa & 1 & 1 & 1 & 1 & 4 \\
\hline & Rangwe & 1 & 1 & 1 & 1 & 4 \\
\hline \multicolumn{2}{|r|}{ TOTAL } & 4 & 4 & 4 & 4 & 16 \\
\hline \multicolumn{2}{|c|}{ GRAND TOTAL } & 12 & 12 & 12 & 12 & 48 \\
\hline
\end{tabular}

\subsection{Data Collection Instruments}

\subsubsection{Semi-structured Interview Guide}

Interview schedules were used to collect data on mobile phone users' capabilities on mobile phone money use.

According to Kombo and Tromp [21], a semi-structured interview gives in-depth information gathered by use of open-ended questions. Quinn [22] agrees with Kombo and Tromp on the purpose and nature of semi-structured interviews. This study used face-to-face interviews to collect information from all informants.

\subsubsection{Focus Group Discussions}

The study used 4 focus groups of 8 participants per group. The 8 participants were in line with gender consideration as well as age consideration. The rural and urban settings were also considered in this study. Kombo and Tromp [21] posit that special pre-determined criteria should be used in selecting focus group participants. The interviewer created a supportive environment, asking focused questions to encourage discussion and the expression of differing capabilities and functionings and points of view with respect to the use of mobile phone money services.

\subsubsection{Participant Observation}

Participant observation played an important role when examining capabilities of mobile phone users on mobile phone money use. Compared to other qualitative methods of data collection, participant observation helped in explaining qualitative findings by providing the contextual meaning behind other data generated by interviews and focus group discussions as reiterated [23]. Participant observation was applied at the same time as other forms of data collection, as well as the analysis of secondary data. The participant observation was further used to explain apparent contradictions in other data as also seen in the works of Stephen Koester [24].

\subsection{Theoretical Framework}

This study adopted Amartya Sen's Capability approach. Over the last decade, Capability Approach has emerged as the leading alternative to standard economic frameworks for thinking about poverty, inequality and human development generally. This framework was established to be appropriate for this particular study in understanding mobile phone users' capabilities and freedoms on mobile money use.

\section{Discussion}

\subsection{Capability Approach}

The capability approach is a broad normative framework for the evaluation of individual well-being and social arrangements, the design of policies and proposals about social change in society. The capability approach is used in a wide range of fields, most prominently in development thinking, welfare economics, social policy, and political philosophy. It can be used to evaluate a wide variety of aspects of people's well-being, such as individual well-being, inequality and poverty. It can also be used as an alternative evaluative tool for social cost-benefit analysis, or to design and evaluate policies.

In academia, it is being discussed in a philosophical term, but also used for applied and empirical studies. In development policy circles, it has provided the foundations of the human development paradigm [25].

The core characteristic of the capability approach is its focus on what people are effectively able to do and to be, that is, on their capabilities. This contrasts with philosophical approaches that concentrate on people's happiness or desire fulfillment, or on theoretical and practical approaches that concentrate on income, expenditures, consumption or basic needs fulfillment.

Sen [26] argued that in social evaluations and policy design, the focus should be on what people are able to do and become, on the quality of their life, and on removing obstacles in their lives so that they have more freedom to live the kind of life which, upon reflection, they find valuable. "The capability approach to a person's advantage is concerned with evaluating it in terms of his or her actual ability to achieve various valuable functionings as a part of living [26].” 
Martha Nussbaum has advanced capability approach in somewhat different directions and has used the capability approach as the foundation for a partial theory of justice [27]

A key analytical distinction in the capability approach is that between the means and the ends of well-being and development. Only the ends have intrinsic importance, whereas means are only instrumental to reach the goal of increased well-being and development.

Well-being and development should be discussed in terms of people's capabilities to function, that is, on their effective opportunities to undertake the actions and activities that they want to engage in, and be whom they want to be. These beings and doings, are what Sen calls achieved functionings, and together they constitute what makes a life valuable. Functionings include working, resting, being literate, being healthy, being part of a community, being respected, and so forth.

The distinction between achieved functionings and capabilities is between the realized and the effectively possible, in other words, between achievements and freedoms. Ultimately, the most important is that people have the freedoms (capabilities) to lead the kind of lives they want to lead, to do what they want to do and be the person they want to be. Once they effectively have these freedoms, they can choose to act on those freedoms in line with their own ideas of the kind of life they want to live. For example, every person should have the opportunity to access services of mobile phones and access services of any of the available mobile network operators, but if someone prefers not to be part of this service, they should also have this option. This means that the capability approach is clearly a theory within the liberal school of thought in philosophy. The word 'liberal' in political philosophy refers to a philosophical tradition, which values individual autonomy and freedom [28][29], and should not be confused with the word 'liberal' in daily life. In daily life 'liberal' has different political meanings in different countries, and can cover, both the political right, or left. In additional it is often used to refer to (neo-) liberal economic policies which prioritize free markets and privatization of public companies such as water suppliers or the railways. In contrast, philosophical liberalism is neither necessarily left or right, nor does it a priori advocate any social or economic policies.

\subsection{Mobile Phone Users Functionings and Freedoms (Capabilities)}

From field interview data, it was very clear that functionings and freedoms that mobile phone users have are diverse and are dependent on environment. This study was spot on in considering both rural and urban settings, as well as covering the gender diversity and age diversity in the study area. The funtionings and freedoms therefore differed from one setting to the other. In the study area, the study established that mobile money use functionings included user literacy levels, availability of Mobile Network Operators (MNO) agents, e-floats, till numbers and paybill numbers among others.

\subsubsection{Literacy as a Functioning}

The study established that in the rural communities many mobile users perceived mobile money services as a technology meant for those who were educated. They were only comfortable using remittance bit, which included sending money to friends and relatives as well as receiving money and withdrawing. The other aspects of mobile money services like use of paybill numbers and till numbers to enhance cashless transactions were perceived to be favorable to educated users. This puts literacy as one of the functionings that enable mobile phone users to attain freedom of using mobile money service.

Related to literacy was language barrier which was yet another reason that led to low use of mobile money services in the study area, especially when one sends money to a wrong person, and the only way out of retrieving the amount back involves contacting customer care who speaks in Swahili and English languages only, hinders many users who found themselves in such a circumstance, from seeking reversal of transactions. To enhance freedom in mobile money use, it is critical to eliminate barriers of language among mobile phone use, so that they find it easy and fun to use mobile phone money services to perform the various transactions. When users who are challenged to speak in English and Swahili languages commit any mistake during financial transactions through their mobile phones, or send money through their mobile phones to wrong recipients, to follow up for the reversal of transactions require them to reach out to customers care people of the various MNOs. These customer care representatives could only be addressed in only English and Swahili languages. Those users who were challenged in these languages found it challenging to follow up on such wrong transactions to request for reversal. As such they used this language barrier with customer care representative as a necessary excuse to avoid using mobile phone money services. Tere was therefore a strong need of eliminating such barriers for the users in that kind of state to be able to attain full freedoms (capabilities) of using mobile phone money services.

The findings concurred with two other studies from the economic development and practitioner literature, by Ivatury and Pickens [30] and Porteous [31], that suggested that, mobile money users in South Africa were wealthier and better educated than the average South African with a bank account, let alone the average unbanked South African. Being educated meant that they would be able express their plight whenever it required that they seek the services of customer care. Being wealthy on the other end meant that they had financial resources to deposit in their mobile phone money account for transactions. Looking at 
this finding, it was evident that, lack of education was one of the major barriers to those who were illiterate in attaining freedoms of use.

\subsubsection{Confidentiality as a Functioning}

A study conducted of consumers in Germany by Werthner, Tschammer, Foeschl, and Pousttchi. [32], identified confidentiality of data as the most important concern with mobile money, even outweighing the concern that such systems will impose direct costs upon the consumer. A majority in the same study indicated that anonymity in transactions was a key function serving consumers' overall interest in confidentiality and as such needed to be given the top priority. Similarly, a focus group study of Finnish consumers in 2001 and 2002 found that, "some of the informants were unwilling to trust their personal information with the payment service providers. They were concerned that, their purchases would be tracked or that they would begin to receive a lot of advertisements" [33]. As such, there is an indication that some existing evidence that consumer privacy concerns may pose a barrier to mobile money system uptake, and as a barrier it hinders full attainment of freedoms (capabilities) of mobile phone money use by all the willing users.

\subsubsection{Economic Status as a Functioning}

The study further established that the rural community of Homa Bay Region where study was conducted perceived mobile money payment as a technology for those who were of relatively higher economic status in the society. The study established that the rural poor in their opinion that, only those who were of relatively higher economic status in the society were the ones who were either ready to make good use of mobile phone payment innovation in the rural communities. They perceived that the wide range of services offered by mobile phone money service was only available on smart phones that they perceived to be costly and could only be acquired by those with relative higher economic status. To them, economic status or class was a necessary determinant to extensive use of mobile phone money services.

This made economic status of individuals a factor to either enhance or restrict individuals from the full use of mobile money services. The poor communities that believed on the fallacy that only smartphones could access all the various services of mobile phone money services, ended up having economic status being a barrier to their full attainment freedom of full mobile phone money use.

\subsubsection{Possession of National Identification Card as a Functioning}

Another factor that was established to be a barrier especially in the rural communities of Kenya to mobile phone money utilization was lack of the national Identification (ID) cards especially by most women below the age of 30 years. Since it was a requirement by
Communications Authority of Kenya; a Kenyan telecommunication regulator; that all Mobile Network Operators (MNO), register all their subscribers and this process of registration required an individual to be in possession of national ID card, and thus, those without national ID cards technically found themselves excluded from this innovation. This is against their quest to attain full freedoms (capabilities) of using mobile phones and by extension mobile phone money services. Also to withdraw and deposit of money in one's mobile phone from a MNO agent require an individual to present a National Identification card ID for identification and verification transaction.

Further, to have access to mobile phone money services offered by any of the MNOs, you were required to register separately for the service. This process equally required the intended users to be in possession of national ID cards. Therefore, national ID card was a major factor that negatively influenced mobile phone money utilization, majorly in the rural communities; especially the young women who were not in possession of these valuable documents. National ID cards therefore, was a hindrance for the full attainment of freedom of use of mobile phone money services, by all the interested mobile phones users.

Enhancing mobile phone money services as development where everyone could chose to or not chose to adopt required that every citizen that had reached the age of acquiring a National ID card, be issued with one. There should also be a way of fast tracking replacement of the National ID cards to those who in one way or another misplaced their copies. This would go a long way enhancing many people who are interested in both the rural and urban areas attain full freedoms (capabilities) of mobile phone money use.

The researcher inquired some of the reason that had resort to a number of potential users who were eligible to possess national ID cards, lacking ID cards, and it was realized that partly it was a perception issue. Mainly among the rural communities, there was a strong perception that the process of acquiring national ID cards was more tedious and that a number of documentation were needed. The young women perception was that they would be required to be in possession of a number of documents, some of which they would be unable to access and avail to facilitate their National ID issuance. This perception kept off many of them from making any attempt of looking for these vital documents. In return this further denied them the necessary condition of attaining their full freedoms (capabilities) of full mobile phone money use.

\subsubsection{Information/Knowledge on the Elements of Mobile Phone Money Services}

The study also established that most of the mobile phone users had inadequate information on mobile phone money and the elements of mobile phone money. Majority of the users in the rural setting, were mainly aware of the element 
of sending and receiving money through mobile phone. However, they were more surprised when they heard from other users during FGDs, elaborating the other elements of mobile phone money services such as buy goods and pay bill elements. What was more surprising to them was that even their mobile phones, for those who had registered for mobile money services such as M-Pesa, Airtel money among others, had access to such elements. This was therefore a proof that many users were unaware of the potential of the technology that they had. Similar to ignorance and illiteracy, this condition barred a number of the mobile users, especially in the rural communities from attaining full freedoms of mobile money use. For this reason, there are those potential users who fail to use all the available mobile phone money services, simply for lack of awareness of existence of such technological innovations. They perceived that, their mobile phones were only capable of making calls, sending short messages as well as only doing remittances of money. This means that awareness was one of the functioning that enhances full realization of mobile phone money services freedoms.

Contrary to those who did not have access to this technology, some of the users had access, but were not aware of the wide ranges of services that their mobile phone money technology could offer to them. This too was another major factor that negatively influenced mobile phone money use in the rural parts of the study area. This was similar to some of the concerns raised by Suri and William [34], in their study conducted in Kenya, involving M-Pesa users and non-users to establish the profile of MPesa's early adopters and customer usage patterns. Their study established that the average M-Pesa user was, in comparison to non-users, was twice as likely to have a bank account, wealthier, more literate, and better educated. This showed that a greater majority of the rural poor community were not aware of the existence certain innovations, even those that were available in the gadgets that they already possessed. This clearly illustrated that user awareness of innovation or technology is functioning that propels realization of one's freedoms and such cannot be ignored.

Inadequate information on mobile phone money was also major challenge facing the users in the study area from utilizing mobile phone money service, especially in the rural communities. This challenge influenced on whether to use or not to use mobile phone money services in the study area. Most of the people claimed to have better understanding of mobile money use, but on further interrogation, the researcher established that they were mainly aware of the aspects of sending and receiving money (remittances). Most of the mobile phone money users lacked the information that mobile phone money could as well be used to buy goods through the use of till numbers and payment of utility bills as long as the utility service provider had a business number from MNOs.

Suri and William further established that early adopters appeared to be experienced with banking propositions and were fairly technology savvy, which probably made them more acutely aware of the convenience offered by M-Pesa relative to other alternatives. This was similar to what was established in Homa Bay region, where those who had not been using other elements of mobile phone money such as payment of bills and buying of goods among others, lacked the information on the existence of such innovations. They too were not technology savvy, and therefore remained passive users of this kind of technology. This categorically meant that most of the potential users were unaware of a wide range of mobile phone money service. Being aware of the existence of any new innovation would be quite instrumental functioning for use. This is because, users only embrace what they were aware of, therefore awareness becomes another potential functioning that influenced mobile phone money, and in the rural part of the study area, it influenced greatly leading to negative outcome, being that many mobile phone users, were not aware of all the elements they could have access to within their phones.

\subsubsection{Security as Functioning}

Drawing from representative survey data, conducted by Porteous [31], where mistrust and unawareness were among the primary reasons South Africans might choose not to use mobile banking as well as mobile money. According to Porteous, in South Africa majorly mistrust and unawareness were the primary reasons that led to low use of mobile banking as well as mobile phone money services. Mistrust comes from fear of their security being compromised. Many users would therefore refrain from the use of this technology, which in turn would lead to many not achieving their full freedoms in mobile money services.

\subsubsection{Ease of Use}

Mallat [35] on his study established that Finnish consumers found SMS based payments to be complex and slow to use. SMSs were heavily criticized because the message formats are often complicated, the service numbers are difficult to remember and instructions can be hard to find. Therefore Mallat suggested that SMS was not the best possible technology used for mobile payments in Finland. This was also true to the study area, especially the rural parts, where there were a number of users who were illiterate. Such users were uncomfortable with the technology as it locked most of them out, and therefore, the reason as to why they disclosed their secret PIN numbers to mobile phone money agents or other people such as their relatives, an act that compromised on the security of their mobile money. This makes complexity of technology and in this case ease of use of technology as a functioning that could have impact on users' capabilities.

Citibank report [36] also puts it that, mobile phone money as a product was much more complicated to sell 
than airtime. Selling airtime was quick and simple for the user to understand. By contrast, a mobile money agent would most likely have to answer a number of user questions. That was, they might even need to complete a transaction on behalf of the user to demonstrate how it was done, a move that required trust between the agent and the user. This meant that MNOs had to invest in agent training up front [36]. More so, because higher commissions could mean higher transaction fees for the user, and there were often tradeoffs between agent profits and financial inclusion objectives. Therefore, eliminating complexity would enhance uptake of mobile money service and thus increasing development by having many phone users achieving their freedoms of use.

\subsubsection{Mobile Money Service Agents}

Availability and distribution of MNOs mobile money agents was yet another functioning established to contribute to attainment of freedoms of mobile phone users when it comes to mobile money services. In the study area, especially among the rural communities, there existed a few MNO agents. In addition to the few agents available in the rural parts of the study area, the agents always had limited cash and $e$-float to trade with. Availability of agents as well as cash and e-floats were seen as some of the functionings that enhances attainment of freedoms, in this case mobile phone money use.

The inadequate number or lack of agents, cash as well as e-floats was clear evidence to the low uptake of mobile money services mostly rural communities. The study further established that, the only days that mobile phone money agents at least had much money and e-float to serve more customers were during designated market days. It would be non-logical to expect many people in such areas to attain freedoms in using mobile money services, unless such functionings are availed to all the users.

\subsubsection{Transaction Service Speed}

Delays during transactions using mobile phone money was another major concern that a few informants experienced, perceived as a potential hindrance to mobile phone money use. Most of the users got irritated when they were forced to wait for long minutes or even hours on the event of transaction delays. Most of the users who had experienced delay in the past preferred to carry out cash transactions as opposed to fear of experiencing delays. Many argued that this could any day be disastrous, especially in cases of emergencies that would require money urgently. Therefore, to many people, this condition would be a demotivator to embrace mobile phone money innovation or to use.

This led to some users and potential users to have subjective view of this innovation, which negatively influenced their behavioural intention to use. The delays experienced when transacting using mobile phone money services to send, receive money, to buy goods or paybills, which also posed as another challenge. This was not specific to any part however; it was cutting across the entire study area, whether urban or rural. This discouraged many users from fully embracing mobile phone money services, especially those who were always impatient.

The delays could be attributed to by a number of factors. They could be as a result of the network strength, which is dependent on infrastructural support. All these had impact on mobile phone users' attainment of freedoms that they desired of enjoying mobile money services.

\subsubsection{Infrastructure and Cellular Connectivity}

Balan, Ramasubbu, Prakobphol, Christin, and Hong [37], established in their work that one disadvantage of mobile money services was that it required infrastructure support from the mobile network operators. Further, payments could not be made if there were no mobile phone reception. Basically, this meant that SMS based payments may not work in remote places with the challenges of connectivity in terms of network.

This was similar to the challenge that users at times faced on transaction delays in the study area. This indicated that network connectivity was not that perfect, since there were instances when fluctuations existed that resulted in transaction delays or even termination, which was experienced across the entire study area, both rural and urban areas alike. Infrastructural support and connectivity was therefore instrumental in enhancing transaction speeds which would go a long way in facilitating mobile phone users attain the freedoms they are interested in when it comes to mobile money services.

Balan et al., further, stated that even stormy weather could cause problems to the cellular network infrastructure making it impossible to make SMS-based payments. Cellular network connectivity would therefore be considered as another functioning that enable phone users attaining freedoms of mobile money services.

\section{Conclusions}

In conclusion, it is of utmost significance to eliminate all the barriers to mobile money use, or rather enhance all the functionings that facilitate the attainment of mobile money services freedoms among the mobile phone users.

According to Kenya's Economic Survey of the year 2003 [38], the major Information Systems and mobile technology challenges in the Kenya consisted of poor and inadequate information systems, inadequate IT infrastructure, limited skills in ICT, lack of appreciation of ICT, technology weaknesses exhibited by heavy reliance on inappropriate and obsolete technology, lack of skills on modern technology, lack of awareness of the changing technology, poor dissemination mechanisms between and among the various levels of enterprises, and poor technology linkages between the private and public sector 
institutions. This concurs with the findings established by the study that clearly showed lack of awareness on the wide range of services offered by mobile phone money services.

Majority of mobile phone money users in the study area were only aware of aspects of remittances and no other available services like use of Pay Bills and Buy Goods services, buy airtime among others. All these must be reduced if not eliminated. Eliminating them would offer most phone users opportunities to attain the much-needed freedoms of mobile money services.

A study by Alqahtani, Al-Badi and Mayhew [39] in Saudi Arabia that investigated the factors, that made the mobile subscribers reluctant, as well as the factors that made mobile phone users keen to accept mobile transaction. The findings of their study showed that the factors that had the most significant influence on the acceptance and use of mobile transaction in Saudi Arabia were: usability, usefulness, telecommunications infrastructure, security, hacking and fraud, availability, trust, payment gateway, awareness, cost and promotion, privacy, cyber-law, the postal services, government e-readiness, Arabic language support among other factors. Some of these findings in a way are replicated in this study. Just as in Saudi Arabia, the study established challenges caused by factors such as trust issues when it comes to utilization of mobile money services, security issues as well as fraud. These challenges; trust, security and fraud, requires proper measures, if $\mathrm{MNO}$ were to satisfy mobile phone money users, and consequently to enhance attainment of mobile phone users freedoms of mobile money services.

\section{REFERENCES}

[1] Sen, Amartya K. (1999), Development as Freedom, Oxford: Oxford University Press.

[2] Jobodwana, Z. N., (2009). E-Commerce and Mobile Commerce in South Africa: Regulatory Challenges: Journal of International Commercial Law Technology, vol. 4, no. 4, pp. $287-298$

[3] Must, B., \& Ludewig, K. (2010). Mobile money: cell phone banking in developing countries. Policy Matters Journal, Spring, 27-33.

[4] Mas, I. (2009). The economics of branchless banking. Innovations, 4(2), 57-75.

[5] Pickens, M. (2009). Window on the unbanked: mobile money in the Philippines. CGAP Brief, http://www.cgap.org/publications/window-unbanked-mobil e-money-philippines (accessed on 4th August, 2015)

[6] Jack, W., \& Suri, T. (2011). Mobile money: the economics of M-PESA. NBER Working Paper No. 16721. National Bureau of Economic Research, Cambridge, MA.

[7] Pope, C., \& Mays, N. (2000). Qualitative Research in Health
Care. London: BMJ Books.

[8] Denzin, N. K. \& Lincoln (2011). The Sage Handbook of Qualitative Research. Sage Publications: USA.

[9] Iacono, J. Brown, A., \& Holtham, C., (2009). Research Methods - a Case Example of Participant Observation: Electronic Journal of Business Research Methods Volume 7 Issue 12009 (39 - 46)

[10] Myers, M.D. (1999). 'Investigating Information Systems with Ethnographic Research' in Communications of the AIS, Vol. 2, Article 23 pp. 1-20

[11] Reeves, Kuper and Hodges. (2008). Qualitative research methodologies: ethnography. British Medical Journal. 337:a1020.

[12] Homa Bay CIDP, (2013). The First County Integrated Development Plan 2013 - 2017

[13]. KNBS, (2014b). Single and Grouped Ages in years by County and District, Kenya National Population and Housing Census of 2009

[14] KNBS, (2014a). Access to Mobile Phone Service by County and District, Kenya National Population and Housing Census of 2009. (Accessed on 13 ${ }^{\text {th }}$ July, 2015, from: http://www.knbs.or.ke/index.php?option=com_phocadownl oad\&view=category\&download=414:access-to-mobile-pho ne-service-by-county-and-district\&id=99:detailed-census-re sults\&Itemid $=639$ )

[15] Bailey, C. A., (2007). A Guide to Qualitative Field Research. ( $2^{\text {nd }}$ Edition). London: Pine Forge Press.

[16] Amin, E. M., (2005). Social Science Research, Methodology and Analysis. Kampala: Makerere University.

[17] Flick, U. (1998). An introduction to qualitative research: Theory, method, and applications. London: Sage.

[18] Morse, J. M. (1995). The significance of saturation. Qualitative Health Research, 5, 147-149.

[19] Strauss, A., \& Corbin, J. (1990). Basics of qualitative research: Grounded theory procedures and techniques. Newbury Park, CA: Sage.

[20] Kothari, C.R., (2003), Research Methodology-Methods and Techniques, New Delhi, Wiley Eastern Limited.

[21] Kombo, D. \& Tromp, D (2006). Proposal and Thesis: An introduction. Nairobi. Pauline's Publication East Africa.

[22] Quinn, M. (2002). Qualitative research and evaluation methods. Minesota: Sage Publications

[23] DeWalt, K., \& DeWalt, B. (2011). Participant observation: A guide for fieldworkers ( $2^{\text {nd }}$ Edition.). Lanham, MD: AltaMira.

[24] Koester, S., \& Hoffer, L., (1994). Indirect sharing: Additional risks associated with drug injection. AIDS and Public Policy 1994, 9(2), 100-105.

[25] Fukuda-Parr, S. (2003), .The Human Development Paradigm: Operationalizing Sen's Ideas on Capabilities. Feminist Economics, 9(2-3), 301-317.

[26] Sen, Amartya K. (1993), .Capability and Well-being, in Martha C. Nussbaum and Amartya K. Sen (eds), The Quality 
of Life, Oxford: Clarendon Press, pp. 30. 53.

[27] Nussbaum, M. C. (1988), Nature, Function and Capability: Aristotle on Political Distribution. Oxford Studies in Ancient Philosophy, Supl. Vol., 145.84

[28] Kymlicka, Will (2002) Contemporary Political Philosophy. An Introduction. 2nd ed. Oxford: Oxford University Press.

[29] Swift, Adam (2001) Political Philosophy: A Beginner's Guide for Students and Politicians. Cambridge: Polity.

[30] Ivatury, G., \& Pickens, M. (2006). Mobile phone banking and low-income customers: Evidence from South Africa. Washington, DC: Consultative group to assist the poor (CGAP) and the United Nations Foundation.

[31] Porteous, D. (2007). Just how transformational is m-banking? Retrieved 10 August, 2015, from http://www.finmarktrust.org.za/accessfrontier/Documents/tr ansformational_mbanking.pdf

[32] Werthner, H., Tschammer, V., Foeschl. K. \& Pousttchi, K. (2003). Conditions for Acceptance and Usage of Mobile Payment Procedures, in Giaglis, G. M.: The Second International Conference on Mobile Business. Vienna 201-210 (2003).

[33] Dahlberg, T., Niina, M. \& Anssi, Ö. (2003). Trust Enhanced Technology Acceptance Model - Consumer Acceptance of Mobile Payment Solutions: Presentation at Stockholm
Mobility Roundtable Stockholm Sweden May 2223:10 (2003)

[34] Suri, T. \& William, J. (2008). The performance and Impact of M - PESA: Preliminary Evidence from a Household Survey. Unpublished Paper

[35] Mallat, N. (2007). Exploring Consumer Adoption of Mobile Payments. A Qualitative Study. The Journal of Strategic Information Systems, 16 (4), 413-432.

[36] Citibank (2012), 10 Ways to Accelerate Mobile Money: USAID-Citi Mobile Money Accelerator Alliance. Viewed on $20^{\text {th }}$ February, 2016, From: http://www.citibank.com/transactionservices/home/public_s ector/docs/Mobile_Money_Article.pdf

[37] Balan, R. K., Ramasubbu, N., Prakobphol, K., Christin, N., \& Hong, J. (2009). mFerio: the design and evaluation of a peer-to-peer mobile payment system. MobiSys '09 Proceedings of the 7th International Conference on Mobile Systems, Applications and Services.

[38] Government of Kenya (2003). Economic Survey 2003. Central Bureau of Statistics Government Printers, Nairobi.

[39] Alqahtani M. A, Al-Badi A. H., \& Mayhew P. J., (2014). Exploratory Study of M-Transaction: User's Perspectives. The Electronic Journal on Information Systems in Developing Countries. 60, 7, 1-22. (Retrieved on $10^{\text {th }}$ September, 2015 from: (http://www.ejisdc.org) 